\title{
Evaluation of Environment Policies in Turkey's Development Plans
}

\author{
Yaşar Akça ${ }^{1}$, Melih Öztürk ${ }^{2} \&$ Ali Namık Güneş ${ }^{3}$ \\ ${ }^{1}$ Faculty of Economics and Administrative Sciences, Bartın University, Bartın, Türkiye \\ ${ }^{2}$ Faculty of Forestry, Bartın University, Bartın, Türkiye \\ ${ }^{3}$ Faculty of Engineering, Bartın University, Bartın, Türkiye \\ Correspondence: Yaşar Akça, Faculty of Economics and Administrative Sciences, Bartın University, Bartın, \\ Türkiye.
}

$\begin{aligned} & \text { Received: March 1, } 2018 \\ & \text { Accepted: March 25, } 2018 \quad \text { Online Published: May 14, } 2018 \\ & \text { doi:10.5539/jms.v8n2p28 }\end{aligned} \quad$ URL: https://doi.org/10.5539/jms.v8n2p28

This article was presented orally in I. International Congress on Social Sciences Humanities and Education, 22-23 December 2017, Istanbul/Türkiye.

\begin{abstract}
Turkey's five years development plans had been prepared by State Planning Organization (SPO) before 2011; since that time, Ministry of Development has been preparing these plans. The plans include the resources of development goals and preparations that are necessary in order to reach these goals. There are ten development plans including the years between 1963 and 2018. The basic goal of all these development plans is to ensure Turkish citizens have a fortunate and prosperous life. The environment, which is the topic of the article, is the setting in which human continue his biologic, economic, social and cultural life. The significance of the environment is increasing especially in terms of production, employment and trade day by day. The goal of this study is to review environment policies included in the development plans, to analyze their relations with other policies, to bring up Turkey's environmental problems to the agenda and to develop solution suggestions to these problems. Development activities should be carried out without causing any damage to the environment. Protection of environment should be prioritized during the processes of urbanization and industrialization. This research is based on qualitative design document analysis technique and environment policies that are mentioned in ten development plans are analyzed. Rather than coping with the environmental pollution, it is much more economic to take precautions in order to prevent it.
\end{abstract}

Keywords: development plans, environment policy, environmental effect evaluation, air pollution, water pollution, soil pollution

\section{Introduction}

The main goals of development are to meet the necessities of public, to increase welfare level and to provide new employment opportunities. Significant and interrelated parts of development rely particularly on the cooperation among management, businessmen and public. It is possible to ensure development in a country through increasing investments. In this frame, development plans include organizations and arrangements which shall be done in order to determine the resources to be used, the workforce to be mobilized and precautions to be taken. The main goals of development plans are to ensure production with high added-value, to increase productivity and agricultural development, to increase the share of industry and employment, to decrease unemployment, to end the income inequality and to increase income level of the low-income group, to support the economy of regions under development priority and to empower social substructure. Environment is one of the main elements of human prosperity and happiness. A prosperous society is possible only with a healthy environment. Social development should focus on future generations and ensure a future based on a harmony with nature. Environment is the setting in which human and other living beings exist (Budak, 2000: 21). It is impossible to have a happy and prosperous life and ensure development without breathable clean air, drinkable clean spring water and productive agricultural soil. 


\section{Environment Policies in Turkey's Development Plans}

The main goal of state is to ensure the prosperity and peace of the public. Development, production and consumption goals necessitate determining policies and taking steps on the basis of these policies. Environment policies are necessary in order to ensure development without degrading the environment. Environment policy means determining the desired issues and taking precautions in order to prevent environmental problems (Budak, 2000: 22). There are 10 different development plans for a period of 55 years; there is almost no environmental issue in the first, second, third and eighth five years development plans. Development plans that are affirmed by The Grand National Assembly of Turkey, are binding for the public while they are incentive for private sector (Keleş et al., 2012: 523). Environment Policies in the above mentioned development plans are analyzed and evaluated in the following sections. Since the environmental policies are particularly addressed after the third development plan, the evaluation of those policies begins initially with the fourth development plan.

\subsection{The Fourth Five Years Development Plan (1979-1983)}

Because of the increase in the amount of waste which caused environmental pollution, it is crucial and compulsive to treat the sewage and water system together in the locations, where clean and drinkable water is intended to be obtained (SPO, 1979: 78). Transportation policy based particularly on the petroluem and private transport has increased air pollution and caused serious environmental problems (SPO, 1979: 78). Solving environmental problems such as degradation of nature and environment, destruction of soil and water resources, air pollution, and disruption of ecological balance was the generally accepted main policy in that period. The issues of ecological basins' pollution toleration, compensation, prevention and self remediation capacities couldn't be analyzed and presented in details within that period. Besides, in the time period mentioned above, water and sewerage systems were problematic whereas, soil erosion and forest ecosystems were destroyed. Because of rapid urbanization and associated inadequate substructures, water pollution has become significant problem (SPO, 1979: 83). Due to the inadequate water treatment infrastructures of most of the industrial establishment, they had to discharge their waste water directly into seas, leading to a serious increase in water pollution. Insufficient sewage systems, solid wastes and various kinds of garbage were the other causes of marine pollution in Turkey. Low quality and performance fossil fuels, increase in the number of private transportation, stack gas emission originated from industries were the major causes of air pollution (SPO, 1979: 84). Inharmonious urbanization, destruction and alteration of productive agricultural lands for sake of urbanization and human settlement were the causes of soil pollution. On the other hand, traffic noises in the metropolitan cities have been causing significant stress on people (SPO, 1979: 85).

\subsection{The Fifth Five Years Development Plan (1985-1989)}

Urban sprawl, soil erosion, rapid industrialization, modernization and mechanization in agriculture were the significant environmental problems in Turkey. The fundemental objective towards to overcome these environmental problems shouldn't only be based upon eliminating the already existing pollution. But also be based upon protection and development of the natural resources in a way that they could be used by future generations. It was determined that the factor of environmental concerns shall be taken into consideration while planning and proposing projects for future investments and organizations and therefore wastes of industrial facilities shall be under control (SPO, 1984: 171).

\subsection{The Sixth Five Years Development Plan (1990-1994)}

Protection of environment through the usage of cultural and natural resources while managing socio-economic activities was the main goal (SPO, 1989: 3). Land and environment which were destroyed during the mining operations will be determined. Besides, taking the necessary precautions together with conducting the administrative and legal arrangements in order to make those land environmental resources reusable constitute other significant goals of this perod (SPO, 1989: 66). Industrial facilities shall be controlled and reorganized in a way that they had environmental compatibility (SPO, 1989: 93). Damages of toxic and contaminating gas emissions shall be prevented (SPO, 1989: 276). Ensuring economic development through preserving balance between human health and nature, protected environment to future generations were the basic principles. Environmental consciousness shall be conveyed to general public. Industrial facilities, infrastructures, housing and touristic facilities shall not be established on the first three classes of agricultural fields (SPO, 1989: 312). Factors that cause air pollution in cities shall be carefully determined and closely monitored (SPO, 1989: 313). 


\subsection{The Seventh Five Years Development Plan (1996-2000)}

It was determined that the use of opportunities supplied by technology would make significant contributions (SPO, 1995: 4). Organizations and arrangements for the environmental protection were insufficient (SPO, 1995: 96). Environmental Impact Assessment shall be taken into consideration while making investments (SPO, 1995: 147). Green spaces shall be formed inside and within the vicinity of the cities (SPO, 1995: 178). Applications and practices for preventing air and water pollution, domestic and industrial wastes, change in soil, air and water quality had been limited until that period. Changes in the soil, air and water quality because of environmental changes shall be prevented as soon as possible; implementations in order to prevent unfair competition shall be made (SPO, 1995: 191). Environmental recycling practices shall be supported (SPO, 1995: 192).

\subsection{The Ninth Five Years Development Plan (2007-2013)}

The basic goal was to conserve our environment for future generations (SPO, 2006: 3). Although there were improvements and progresses in terms of waste management, protection of nature, noise pollution. There was still a significant need for changes and advancements (SPO, 2006: 28). Amount of waste in industry shall be decreased with the use of environment friendly technologies. Waste collection and classification according to the type of waste, together with transportation and recycling systems shall be established (SPO, 2006: 74).

\subsection{The Tenth Five Years Development Plan (2014-2018)}

Rapidly increasing population, urbanization, various economic activities and consumption because of increasing income have put extra pressure on the environment and natural resources significantly. Environmental pollution, water shortage, desertification, global warming, climate change and deforestation are on today's global agenda. In the frame of green development approach, it is understood that clean production and eco-efficiency helped protection of the environment. The primary objectives are to prevent pollution, use and protection of natural resources and maintain the biological diversity (Ministry of Development, 2013: 13). In order to acquire healthy living spaces and settlements, urban infrastructure facilities and investments are should be planned to be improved. Drinking water, waste water, solid waste and garbage services have been improved (Ministry of Development, 2013: 25). Human environment and quality of workplace environment are the indicators of principle development and prosperity (Ministry of Development, 2013: 117). There have been significant achievements in emission control, expansion of protected areas, maintenance of biological diversity, environmental pollution preventation, increasing environmental quality, sustainability, use and management of natural resources (Ministry of Development, 2013: 136). Use of innovative practices will increase environmental consciousness; leading to the cease of waste and emission in cities, support of productive usage of energy, water and resources, promotion of recycling, prevention of noise and aesthetic pollution, encouragement of environment friendly material (Ministry of Development, 2013, p. 137).

\section{Environmental Problems of Turkey}

It is possible to summarize the main environmental problems in Turkey as such:

- Initially, it is determined that the country lands are under the threat of increasing population and industrialization. Air pollution causes lung cancer and respiratory diseases. Domestic and industrial wastes cause water pollution and serious soil pollution.

- Unplanned urbanization is one of the most significant environmental problems of today. Illegal and shanty housing, narrow streets, houses without garages or parking lots, neighborhoods without green spaces shape and constitute the general frame of cities.

- Agricultural fields around the cities have been destroyed in time while plains and meadows have been utilized for housing purposes (Öztürk et al., 2017).

- Coasts that should commonly be used by public for touristic, recreational, fishing and shipping purposes are under the threat of urban sprawl. There are settlements, holiday villages, hostels, hotels and motels around Türkiye's beautiful coasts. This situation causes pollution and destroys natural beauty significantly.

- Environmental problems in Turkey aren't limited with cities; rural areas are also victims of pollution. Misuses of agricultural fields are the main problems of rural areas. As a result of chemical fertilizers, soil in these lands become too salty, they become less productive and they lose the agricultural cultivation potential in time (Saysel et al., 2002).

- On the other hand, forest and endemic plants perish in time, which cause erosion, drought and landslides. Settlements on the riparian zones of the rivers and streams increase the risks of flood.

- Opencast mining cause physical and topographic destruction and ecologic degradation. 


\section{Solution Suggestions for Environment Problems}

Suggestions for solving Turkey's environmental problems are presented below:

- Fossil-based energy resources is one of the most significant factors that lead environmental problems (petroleum, coal); so, it is important to minimize the use of such resources.

- Energy consumption shall be based on renewable, environment friendly energy resources such as sun, wind, wave, geothermal, biomass, hydrogen etc.

- Misuse of lands, which is a significant environmental problem in Turkey, can be overcome by sustainable land use plans. Land classification and appropriate land use according to the types and classes of lands are significant. Physical, chemical and ecological features of lands should be analyzed and sustainable use on the basis of these data should be provided.

- Already used old agricultural lands should be remediated for the improvement of reproduction.

- Unplanned urbanization should be prohibited and sustainable urbanization should be enforced through the urban transformation projects. Yet these projects are unfortunately already restricted with the reinforcement of load-bearing systems in buildings, facade renewing and road expanding. Location, scale, consistence, configuration, color and landscape services should carefully be carried out.

- Ring roads (beltways) should be increased in order to prevent air and noise pollution sourced by urban traffic.

- Landscape planning practices in favor of the general public should be sustained.

- Lands that are destroyed because of open-cast mining should be renewed by improvement practices such as planting applications (Görcelioğlu, 2002).

- Establishing renewable energy production facilities in industrial areas will decrease the loss of energy and illegal energy use.

\section{Discussion}

Türkiye's environmental problems and related solution suggestions weren't included in the first three development plan periods starting from 1963. Fourth five years development plan is the first one in this respect. The issues of soil and land uses, which are the basis of today's environmental problems, are initially included in this development plan period. Protection and proper use of resources, which are the basis of sustainability, is mentioned in the fifth five years development plan for the first time. Destruction of lands because of mining practices and rehabilitation of them are especially important in the sixth five years development plan. Increasing public knowledge and conscious about environmental problems are among the goals of this plan period. In the seventh five years development plan, the main issue is to make use of the opportunities presented by technology in order to mitigate the environmental problems. On the other hand, negative and destructive effects of unplanned urbanization are thoroughly analyzed and it is determined that they can be prevented and defeated by forestation practices, increasing green spaces and landscape services. The fact of environmental problems is interrupted in the eighth five years development plan. In the ninth five years development plan, the focus is on the concept of environmental impact assessment and increasing related practices. The tenth five years development plan including the year 2018 focuses on solving environmental problems through analyzing climate change, the issue of sustainability, green infrastructure, ecological and green growth approaches. When the start and progress of development plans are analyzed in details, it can be seen that environmental problems and solution suggestions have a determining role in government policies. After all, development plan which is not environment friendly will never bring peace or happiness and will never succeed. The right to live is possible only when sustainability of all kinds of living beings is ensured. Lessons about environment shall be included in curriculums in every stage of education in order to establish an environmental consciousness. On the other hand, every citizen is responsible for handing down a healthy and livable environment for the future generations. Since it is difficult to solve environmental problems once they appear, it is better to prevent them before they occur. But if they have already started, cleaning and purification steps are very crucial. Environmental impact assessment reports should be prepared while deciding on the making of investment. Destruction of nature should be prevented, intense and effective steps should be taken in order to prevent air, water and soil pollution. "Polluter pays" principle should be established. Domestic wastes and emissions should be decreased, recycling activities should be expanded. Productive and economic use of energy is significant. Firstly, renewable energy use should be supported and developed. Use of environment friendly energy resources should be supported. In the process of protection of environment, European Union Standards should be taken into consideration. 


\section{References}

Budak, S. (2000). Avrupa Birliği ve Türk Çevre Politikası, Ankara: Büke Yayınları.

Devlet Planlama Teşkilatı Müsteşarlığı. (1979). Dördüncü Beş Yıllık Kalkınma Planı (1979-1983), Yayın No: 1664, Ankara. Retrieved from http://ekutup.dpt.gov.tr/plan4.pdf

Devlet Planlama Teşkilatı Müsteşarlığı. (1984). Beşinci Beş Yıllık Kalkınma Planı (1985-1989), Yayın No: 1974, Ankara. Retrieved from http://ekutup.dpt.gov.tr/plan/plan5.pdf

Devlet Planlama Teşkilatı Müsteşarlığı. (1989). Altıncı Beş Yıllık Kalkınma Planı (1990-1994), Yayın No: 2174, Ankara. Retrieved from http://ekutup.dpt.gov.tr/plan/plan6.pdf

Devlet Planlama Teşkilatı Müsteşarlığı. (1995). Yedinci Beş Yıllık Kalkınma Planı (1996-2000), Ankara. Retrieved from http://ekutup.dpt.gov.tr/plan/vii/plan7.pdf

Devlet Planlama Teşkilatı Müsteşarlığı. (2006). Dokuzuncu Kalkınma Planı (2007-2013), Ankara. Retrieved from http://ekutup.dpt.gov.tr/plan9.pdf

Görcelioğlu, E. (2002). Peyzaj Onarım Tekniği. İstanbul Üniversitesi Orman Fakültesi Yayınları.

Kalkınma B. (2013). Onuncu Kalkınma Planı (2014-2018), Ankara. Retrieved from http://ekutup.dpt.gov.tr/plan10.pdf

Keleş, R., Can H., \& ve Aykut, Ç. (2012). Çevre Politikası, 7. Baskı, Ankara: İmge Kitabevi Yayınları.

Öztürk, M., İlyas, B., Ercan, G., \& Ömer, K. (2017). Land use suitability classification for the actual agricultural areas within the Bartın stream watershed of Turkey. Periodicals of Engineering and Natural Science, 5(1), 30-36. https://doi.org/10.21533/pen.v5i1.70

Saysel, A. K., Yaman, B., \& Orhan, Y. (2002). Environmental sustainability in an agricultural development project: a system dynamics approach. Journal of Environmental Management, 64(3), 247-260. https://doi.org/10.1006/jema.2001.0488

\section{Copyrights}

Copyright for this article is retained by the author(s), with first publication rights granted to the journal.

This is an open-access article distributed under the terms and conditions of the Creative Commons Attribution license (http://creativecommons.org/licenses/by/4.0/). 